\title{
THE EFFECT OF INFORMATION TECHNOLOGY BASED FLIPPED CLASSROOM LEARNING MODEL ON THE CREATIVITY AND LEARNING OUTCOMES OF CIVIC EDUCATION AT GRADE IV OF SDN BLIGO
}

\author{
Ninik Fatmawati ${ }^{1}$, Yatim Riyanto ${ }^{2}$, Rr Nanik Setyowati ${ }^{3}$ \\ 1,2,3 Universitas Negeri Surabaya, Surabaya, Indonesia \\ Ininikfendy@gmail.com, ${ }^{2}$ yatimriyanto@gmail.com, ${ }^{3}$ naniksetyowati@unesa.ac.id
}

\begin{abstract}
This study aimed to determine the effect of information technology-based flipped classroom learning model on creativity and learning outcomes for grade four Civics at SDN Bligo. This research was an experimental research with a pretest post test control group design. The subjects of this study were fourth grade students of SDN Bligo Sidoarjo. Data collection techniques were through creativity test and learning outcomes tests. Furthermore, the data were tested by using validity and reliability tests, while the learning tools were tested by expert validation. The requirements of the data analysis test were normality test and homogeneity test. The analytical technique used was t test. In this case, the t-test was carried out twice, first, to determine the initial conditions (pretest) of the experimental group and control group and second, to determine the condition after being given treatment (posttest). The results showed that (1) there was an effect of the information technology-based flipped classroom learning model on the creativity of students on Civics education at the fourth grade of elementary schools; (2) there was an effect of the information technology-based flipped classroom learning model on students' learning outcomes on the Civics lesson at the fourth grade of elementary school. In short, this learning model could be used as a solution for learning from home or online learning that students were currently doing due to the impact of the COVID-19 pandemic
\end{abstract}

Keywords: flipped classroom learning model, information technology, creativity, learning outcomes

\section{PENGARUH MODEL PEMBELAJARAN FLIPPED CLASSROOM BERBASIS TEKNOLOGI INFORMASI TERHADAP KREATIVITAS DAN HASIL BELAJAR PPKN KELAS IV SDN BLIGO}

\begin{abstract}
ABSTRAK
Penelitian ini bertujuan untuk mengetahui pengaruh model pembelajaran flipped classroom berbasis teknologi informasi terhadap kreativitas dan hasil belajar PPKn Kelas IV SDN Bligo. Penelitian ini merupakan penelitan eksperimen dengan desain pretest posttest control group design. Subjek penelitian ini adalah siswa kelas IV SDN Bligo Sidoarjo. Teknik pengumpulan data melalui lembar tes kreativitas dan tes hasil belajar. Selanjutnya diuji menggunakan uji validitas dan uji reliabilitas, sedangkan untuk perangkat pembelajaran diuji oleh validiasi ahli. Persyaratan uji analisis data menggunakan uji normalitas dan uji homogenitas. Teknik analisis yang digunakan adalah uji t. Dalam hal ini uji t dilakukan dua kali, pertama, untuk mengetahui kondisi awal (pretest) dari kelompok eksperimen dan kelompok kontrol dan kedua untuk mengetahui kondisi setelah diberi perlakuan (posttest). Hasil penelitian menunjukkan bahwa (1) ada pengaruh model pembelajaran flipped classroom berbasis teknologi informasi terhadap kreativitas siswa pada muatan pelajaran PPKn kelas IV sekolah dasar; (2) ada pengaruh model pembelajaran flipped classroom berbasis teknologi informasi terhadap hasil belajar siswa pada muatan pelajaran PPKn kelas IV sekolah dasar. Model pembelajaran ini dapat dijadikan sebagai solusi untuk pembelajaran dari rumah atau pembelajaran online yang dilakukan siswa saat ini karena dampak pandemi covid-19.
\end{abstract}

Kata Kunci: model pembelajaran flipped classroom, teknologi informasi, kreativitas, hasil belajar

\begin{tabular}{|c|c|c|}
\hline Submitted & Accepted & Published \\
\hline 07 Juli 2021 & 08 September 2021 & 17 September 2021 \\
\hline
\end{tabular}

\begin{tabular}{|l|c|c|}
\hline Citation & $:$ & $\begin{array}{r}\text { Fatmawati, N., Riyanto, Y., \& Setyowati, Rr. N. (2021). The Effect of Information Technology Based Flipped Classroom } \\
\text { Learning Model on the Creativity and Learning Outcomes of Civic Education at Grade IV of SDN Bligo. Jurnal } \\
\text { PAJAR (Pendidikan dan Pengajaran), 5(5), 1443-1460. DOI : http://dx.doi.org/10.33578/pjr.v5i5.8462. }\end{array}$ \\
\hline
\end{tabular}

\section{PENDAHULUAN}

Muatan pelajaran Pendidikan Pancasila dan Kewarganegaraan (PPKn) merupakan muatan pelajaran yang menitikberatkan pada pembentukan pemahaman tentang kewarganegaraan siswa, melalui pendidikan nilai dan moral dalam rangka membentuk sikap, 
karakter dan kepribadian siswa agar menjadi warga negara Indonesia yang cerdas dan baik (smart and good citizenship) (Mujtahidin, 2017:3). Siswa yang mampu mengenal kepribadiannya sebagai bangsa Indonesia, berakhlak mulia, cerdas, jujur, peduli, saling berbagi, gotong royong, demokratis, terampil dan tangguh melalui penanaman dan pembiasaan nilai. yang berasal dari nilai-nilai luhur Bangsa Indonesia yakni Pancasila, merupakan tujuan dalam pembelajaran muatan PPKn. Pencapaian tujuan muatan pelajaran PPKn mengharapkan tidak hanya agar siswa dapat berpikir kritis, logis, dan kreatif dalam menanggapi isu kewarganegaraan, namun demikian pula dalam proses pembelajaran siswa dituntut agar bisa beperan aktif, bertanggung jawab, dan bertindak secara cerdas dalam berbagai aktivitas bermasyarakat, berbangsa, dan bernegara, serta anti-korupsi, berkembang secara positif dan demokratis guna membentuk pribadi yang berlandaskan karakter-karakter masyarakat Indonesia agar bisa hidup secara berdampingan dengan bangsa-bangsa lainnya, berinteraksi dengan bangsa-bangsa lain dalam percaturan dunia secara langsung atau tidak langsung dengan memanfaatkan teknologi informasi dan komunikasi.

Berdasarkan ruang lingkup jenjang pada pendidikan dasar pembelajaran PPKn meliputi nilai praktis Pancasila, berorientasi pada penanaman nilai, pembelajaran berbasis aktivitas siswa dari kehidupan nyata dan bersifat kontekstual, berdasarkan pada experience centered model curriculum, mengunakan metode modelling, simulasi, game, gelar, teladan, inquirydiscovery sederhana (Santoso, 2019:48). Di samping itu, Lebih lanjut Santoso menjelaskan bahwa agar pmbelajaran PPKn lebih mudah diimplementasikan pada lintas generasi, seyogyanya guru menerapkan metode pembelajaran yang semenarik mungkin bagi siswa, partisipati, inovatif, kreatif, berkelanjutan dan menggunakan media berbasis multi media.

Berdasarkan uraian di atas, dapat disimpulkan bahwa dalam rangka mewujudkan tujuan pembelajaran PPKn tersebut, guru harus selalu tanggap terhadap perubahan-perubahan yang terjadi sehingga mampu membekali diri dengan pengetahuan, kemampuan dan ketrampilan yang diperlukan untuk melaksanakan pembelajaran yang inovatif dan efektif dan memberikan kebermaknaan bagi siswa. Hal ini sejalan dengan berbagai inovasi dan perubahan dalam dunia pendidikan yang senantiasa terjadi dan berkembang pada abad 21 dan era revolusi industri 4.0 saat ini. Seiring dengan tuntutan global, usaha dalam meningkatkan mutu pendidikan harus sesuai dengan perkembangan teknologi, terutama teknologi informasi dan komunikasi yang diimplementasikan dalam proses pembelajaran. Mengingat fakta sebagaimana yang disampaikan Qodir (2018), saat ini teknologi informasi dan komunikasi khususnya gawai dan media sosial adalah dua hal yang sangat erat dengan kehidupan siswa.

Terlebih lagi sejak diterbitkannya Surat Edaran .Nomor 4 Tahun. 2020 Tentang Pelaksanaan.Kebijakan Pendidikan.pada masa darurat penyebaran COVID, dalam Surat Edaran tersebut dijelaskan bahwa proses belajar dilaksanakan di rumah melalui pembelajaran dalam jejaring (daring) atau pembelajaran jarak jauh (PJJ) yang dilaksanakan guna memberikan pengalaman belajar bermakna bagi siswa, tanpa harus terbebani tuntutan untuk menuntaskan seluruh capaian dalam kurikulum untuk kenaikan kelas ataupun kelulusan siswa. Kegiatan dan tugas-tugas pembelajaran Belajar dari Rumah seyogyanya disesuaikan dengan minat dan keadaan masing-masing siswa, termasuk perlu dipertimbangkannya akses, saran dan prasarana maupun fasilitas belajar di rumah. Dalam pelakasanaan kegiatan Belajar dari Rumah, guru memberi umpan balik yang lebih bersifat kualitatif dan berguna bagi guru.

Dalam masa pandemi ini, guru ditantang untuk melaksanakan berbagai inovasi agar pembelajaran tetap bermakna tanpa bertemu secara tatap muka langsung dengan siswa. Pengajar di era sekarang perlu memperhatikan aspek penggunaan teknologi sebagai hal mendasar dalam praktik pembelajaran. Namun demikan, teknologi bukanlah segalanya. Teknologi adalah alat yang dapat dimanfaatkan untuk mendukung 
terciptanya pengalaman bermakna dalam proses belajar mengajar.

Namun kenyataannya, dari data presensi kehadiran dan pengumpulan tugas selama PJJ, rata-rata siswa yang hadir dan berpartisipasi aktif dalam pembelajaran jarak jauh hanya 16 siswa atau hanya $72 \%$ dari keseluruhan siswa yang seharusnya yaitu 22 siswa. Guru sudah berupaya membuat video pembelajaran yang diharapkan dapat memudahkan siswa memahami materi pembelajaran. Namun masih saja pembelajaran daring yang dilaksanakan selama ini mengakibatkan siswa menjadi bosan, pasif, kurang berpikir kritis dan kreatif.

Siswa belum mendapat kesempatan secara maksimal untuk mengembangkan ide-ide khususnya terkait pembelajaran PPKn. Pembelajaran dengan hanya menggunakan media video sebagai ganti ceramah dalam kelas serta metode penugasan soal-soal belum dapat dikatakan sebagai pembelajaran.yang berpusat pada siswa. Guru meminta siswa membaca materi di buku, siswa membuat ringkasan, siswa mengerjakan soal-soal serta belum secara maksimal mengaitkan pembelajaran PPKn dengan kehidupan sehari-hari.siswa.di lingkungannya. Hal ini berakibat siswa menjadi pasif dan sulit mengembangkan ide-ide yang dimilikinya. Selain itu, kebiasaan siswa yang pasif menyebabkan kurang terbiasa mengemukakan pendapat dan tidak berani bertanya walaupun mungkin siswa belum memahami materi yang disampaikan oleh guru. Sehingga berdampak menurunnya kreativitas siswa dan motivasi siswa semakin berkurang. Hal ini juga berpengaruh terhadap hasil belajar yang dicapai siswa. Berdasarkan Penilaian akhir Tema 6 pada pembelajaran semester II tahun pelajaran 2020/2021 yang dilaksanakohan secara online real time dengan goole form berbatas waktu, menunjukkan hasil belajar yang dicapai siswa masih rendah yaitu 8 dari 22 siswa belum mencapai Kriteria Ketuntasan Minimal yang ditentukan yaitu 80 .

Berdasarkan kondisi demikian, guru sebagai pemegang kendali dalam kegiatan pembelajaran harus mampu mewujudkan suasana pembelajaran yang lebih aktif dan menyenangkan.sesuai karakteristik muatan pelajaran, sebagaimana yang disampaikan oleh Suyono (2017:194) bahwa, "Guru sebagai pemegang otoritas mengetahui sepenuhnya materi bahasan yang menjadi tanggung jawabnya dan tidak segan untuk selalu belajar dan mengkinikan pengetahuannya". Dalam upaya meningkatkan pemikiran kritis, kreatif dan kemampuan siswa diperlukan model pembelajaran yang tepat untuk digunakan dalam pembelajaran guna mengasah kreativitas siswa (Nasution, 2011:23). Ketepatan dalam pemilihan model pembelajaran yang diimplementasikan dalam pembelajaran sangat menentukan kemampuan siswa dalam mengembangkan kreativitas dan rasa keingintahuannnya dan meningkatkan hasil belajarnya. Dari sekian banyak model pembelajaran, model pembelajaran Flipped Classroom atau pembelajaran kelas terbalik diharapkan sebagai model pembelajaran berpusat pada siswa yang tepat untuk mendongkrak motivasi dan kemandirian belajar siswa sehingga dapat meningkatkan kreativitas dan hasil belajarnya.

Bergmann \& Sam (2012:125) mengemukakan pendapat bahwa model flipped classroom merupakan model pendekatan pedagogis inovatif yang berfokus pada pengajaran yang berpusat pada siswa dengan cara membalik sistem pembelajaran kelas tradisional yang selama ini guru lakukan. Pada pembelajaran Flipped Classroom terjadi kegiatan pembelajaran campuran di mana siswa terlebih dahulu diberikan konten pembelajaran online bisa berupa video atau konten pembelajaranonline lainnya untuk dipelajarinya, biasanya di rumah, dan pekerjaan rumah dilakukan di kelas dengan guru dan siswa berdiskusi dan menyelesaikan pertanyaan atau permasalahan yang disajkian dalam materi pembelajaran. Interaksi guru siswa lebih dipersonalisasi dengan bimbingan secara daring, bukan.dengan ceramah yang lebih bersifat searah. Mengingat sebagian besar siswa kita saat ini adalah generasi $\mathrm{Z}$ yang dengan senang hati dan mudah menerimanya dikarenakan mereka sudah lahir dan tumbuh dengan kemajuan teknologi saat ini (Ramliyana, 2020). Penerapan model pembelajaran flipped classroom dirasa akan membawa efek yang baik bagi kreativitas dan hasil 
belajar siswa khususnya dalam pembelajaran daring.pada masa pandemi Covid-19 ini.

Beberapa penelitian terdahulu dapat dirujuk untuk mengetahui efektifitas penerapan model Flipped Classrroom. Hasil penelitian menunjukkan adanya pengaruh penerapan model pembelajaran tersebut di kelas. Diantaranya adalah hasil penelitian Enfield (2013) yang menyatakan bahwa penerapan model Flipped Classroom meningkatkan motivasi, keaktivan dan ketrampilan siswa. Sedangkan McCarthy (2016) menyatakan hasil penelitiannya menggunakan Flipped Classroom dapat membantu siswa untuk belajar secara mandiri dengan mendorong siswa untuk menyesuaikan diri dengan pengalaman belajar baru. Selanjutnya hasil penelitian Rokhaniyah (2017) yang mengungkapkan penerapan model Flipped Classroom dapat menimbulkan efek positif bagi siswa dalam hal peningkatan hasil belajar.

Munfaridah (2017) mengungkapkan hasil penelitian yakni penerapan model Flipped Classroom mendorong peningkatan penguasaan konsep, kemandirian dan kreatifitas siswa. Lebih lanjut, model pembelajaran Flipped Classroom dapat dijadikan guru sebagai alternatif untuk menciptakan kegiatan pembelajaran yang interaktif di kelas. Interaktifitas ini, terutama pada saat siswa mempelajari materi dengan bimbingan guru dan saat diskusi dalam kelas diharapkan dapat mendorong berkembangnya kreativitas dan hasil belajar siswa.

Demikian juga hasil penelitian Rochmah (2019) bahwa model pembelajaran Flipped Classroom bisa meningkatkan motivasi belajar, kreativitas dan penguasaan konsep siswa. Dalam artikel jurnal yang berjudul Virtual Flipped Classroom: New Teaching Model to Grant The Learners Knowledge and Motivation yang dilakukan oleh Ismail \& Abdulla (2019) menunjukkan adanya perbedaan antara hasil belajar dan motivasi sebelum dan sesudah menerapkan model Virtual Flipped Classroom. Perbedaan tersebut menunjukkan bahwa model Virtual Flipped Classroom bermanfaat dalam meningkatkan hasil belajar siswa. Dapat dikatakan kemajuan teknologi dan adopsi model Virtual Flipped Classroom, menjadikan proses belajar mengajar dapat dibuat lebih efektif dan menyenangkan.

Secara ringkas dapat dikatakan bahwa berdasarkan tujuan muatan pelajaran PPKn tersebut, salah satunya peserta didik harus berpikir kreatif dalam menanggapi isu kewarganegaraan. Untuk itu, sudah menjadi tugas seorang guru untuk menciptakan pembelajaran yang dapat merangsang peserta didik untuk menjadi insan yang kreatif dengan menerapkan model atau metode pembelajaran yang semenarik mungkin bagi siswa, partisipati, inovatif, kreatif, berkelanjutan dan menggunakan media berbasis multi media serta memanfaatkan teknologi informasi yang erat dengan kehidupan siswa.

Permasalahan rendahnya kreativitas dan hasil belajar di sekolah dasar pada saat ini dapat diselesaikan dengan penerapan model pembelajaran Flipped Classroom berbasis teknologi informasi. Sebab dalam model pembelajaran Flipped Classroom berbasis teknologi informasi siswa dituntut untuk menjadi pebelajar yang mandiri dan diberikan kesempatan yang lebih luas untuk mengembangkan dan menyampaikan ide-idenya berbantuan teknologi informasi yang sangat erat dengan kehidupan kesehariannya agar bisa menjadi insan yang kreatif dalam menanggapi isu kewarganegaraan dan menjadiwarga Negara yang cerdas dan baik (smart and good citizenship).

Penelitian ini bertujuan untuk: (1) untuk mengetahui pengaruh model pembelajaran Flipped Classroom berbasis teknologi informasi terhadap kreativitas siswa pada muatan pelajaran PPKn materi manfaat keberagaman karakteristik individu kelas IV sekolah dasar; (2) Untuk mengetahui pengaruh model pembelajaran Flipped Classroom berbasis teknologi informasi terhadap hasil belajar siswa pada muatan pelajaran PPKn materi manfaat keberagaman karakteristik individu kelas IV sekolah dasar.

\section{KAJIAN TEORETIS}

\section{Model Pembelajaran Flipped Classroom}

Flipped Classroom adalah salah satu pendekatan pedagogis baru dan inovatif yang melibatkan pemanfaatan teknologi yang pada awalnya digagas oleh dua orang pendidik 
berkebangsaan Amerika Jonathan Bergmann dan Aaroon Sams pada tahun 2007 dan mulai populer dibahas di kalangan pendidikan pada tahun 2011. Model pembelajaran Flipped Classroom merupakan pembelajaran yang mengutamakan kemandirian siswa dalam belajar dan memanfaatkan waktu di luar kelas dengan didukung oleh berbagai teknologi, sehingga dapat memaksimalkan waktu di kelas agar membuka peluang bagi siswa aktif terlibat dalam pembelajaran sosial dan kolaboratif (Mazur, Brown \& Jacobsen, 2015:145).

Menurut Song, et al (2017:187) bahwa Flipped Classrom merupakan model pembelajaran interaktif yang didesain secara tepat untuk mendorong pembelajaran yang megaktifkan siswa, sehingga dalam mengembangkan konteks tatanan kemampuan berpikir yang lebih tinggi siswa harus aktif terlibat dalam kegiatan pembelajaran yang bersifat kolaborasi dan pembelajaran berbasis masalah. Pembelajaran interaktif ini dilakukan dengan menukar atau membalik prosedur pembelajaran yang mana pembelajaran konvensional dengan metode ceramah yang umumnya dilakukan di dalam kelas diubah menjadi penyampaian materipembelajaran oleh guru melalui unggahan di media sosial dalam bentuk audio atau rekam suara, video, situs web, permainan dan simulasi dalam sebuah konten dan lain sebagainya. Selanjutnya di dalam kelas siswa secara aktif menggunakan waktunya guna mendiskusikan hal-hal yang belum dimengerti serta memperdalam pemahamannya dengan cara menyelesaikan persoalan dengan tingkat kesulitan yang lebih tinggi atau higher order thinking skill (HOTS) dengan pendampingan dan bimbingan dari guru.

Langkah-langkah pembelajaran flipped classroom menurut Jacob dalam Munfaridah (2017:243) yakni: (1) fase 0, siswa belajar materi sendiri di rumah baik menggunakan buku teks ataupun video; (2) fase 1, pembelajaran di kelas dapat dibagi ke dalam beberapa kelompok heterogen untuk menyelesaikan tugas atau permasalahan yang terkait dengan materi; (3) Fase 2 , guru memfasilitasi berlangsungnya kegiatan diskusi dengan memberikan umpan balik pertanyaan maupun lembar kegiatan; (4) Fase 3, kegiatan belajar mengajar diakhiri dengan kuis untuk mengetahui seberapa jauh siswa paham suatu materi.

\section{Teknologi Informasi dalam Pembelajaran}

Menurut Lucas dalam Rusman, et al (2013:73) mengemukakan bahwa teknologi informasi yaitu semua bentuk teknologi yang diaplikasikan dalam menerima, melakukan proses dan mengirimkan informasi dengan alat elektronik, seperti mikro komputer, mikro mainframe, pemindai barcode, perangkat lunak pemroses untuk lembar kerja komunikasi dan jaringan. Lebih lanjut William dan Sawyer sebagaimana dikutip Abdul Kadir (2003:2) mengemukakan, "teknologi informasi merupakan teknologi yang mengintegrasikan komputasi (komputer) menggunakan saluran berkecepatan tinggi dengan menyertakan data, suara dan video.

Adapun penulis memilih untuk menggunakan platform sosial media telegram untuk mengimplementasikan flipped classroom secara virtual. Alasan yang mendasarinya selain sejak awal PJJ penulis sudah memanfaatkan aplikasi telegram dan siswa sudah familiar dengan telegram adalah beberapa kelebihan yang dimiliki aplikasi telegram antara lain: 1) tersedia secara gratis, 2) bebas dari iklan, 3) bisa mengedit pesan yang sudah dikirim, 4) enjamin keamanan terbaik, 5) Menyediakan fitur channel telegram, 6) memiliki cloud sendiri, sehingga tidak perlu khawatir memori hp penuh, 7) Llebih besar pengiriman filenya, 8) mudah digunakan semua platform, 9) grup bisa menampung sangat banyak anggota, 10) adanya fitur BOT, bisa membuat kuis atau presensi, 11) tersedia profil yang cukup banyak, 12) layanan privasi telegram

\section{Pembelajaran PPKn di Sekolah Dasar}

Winarno (2014:95) menyatakan bahwa muatan pelajaran Pendidikan Pancasila dan Kewarganegaraan (PPKn) bertujuan peserta didik mempunyai kompetensi antara lain: (1) berpikir kritis, logis, dan kreatif dalam menanggapi hal-hal terkait kewarganegaraan; (2) aktif berpartisipasi, bertanggung jawab dan bersikap secara cerdas dalam kegiatan bermasyarakat, berbangsa, dan bernegara, juga anti korupsi; (3) berkembang 
secara positif dan demokratis untuk membentuk karakter diri; (4) berinteraksi dengan negaranegara lain dalam bingkai percaturan dunia secara langsung atau tidak langsung menggunakan teknologi informasi dan komunikasi.

Kompetensi inti pengetahuan dan ketrampilan mata pelajaran PPKn Kelas IV masing-masing dijabarkan menjadi empat kompetensi. Salah satu kompetensi tersebut dirumuskan dalam KD 3.3 dan 4.3 tentang manfaat keberagaman karakteristik individu dalam kehidupan sehari-hari. Untuk mencapai tujuan pembelajaran PPKn berdasarkan ruang lingkup yang telah dirumuskan di atas, peran guru begitu penting. Dalam proses pembelajaran, guru memiliki tugas untuk memotivasi; membimbing; dan menyediakan fasilitas belajar untuk siswa guna mencapai tujuan pembelajaran. Tugas guru yang dimaksud antara lain: (1) mendidik dengan berfokus pada mengarahkan dan mendorong pencapaian tujuan baik jangka pendek maupun jangka panjang; (2) menyediakan sarana dalam rangka mencapai tujuan melalui pengalaman belajar yang ideal; (3) mendukung berkembangnya aspek kepribadian misalnya sikap, nilai-nilai, dan penyesuaian diri (Slameto, 2010:97).

Menurut Heri, Heny, Ajeng, Amallia, \& Ana (2020:29), seorang guru dalam proses pembelajaran memiliki tugas untuk menentukan model maupun metode pembelajaran yang sesuai untuk menyampaikam suatu materi pembelajaran agar tercapainya suatu tujuan dari pendidikan. Hal ini dikarenakan guru mempunyai peran untuk mewujudkan suasana pembelajaran yang kondusif, bermakna, dan menyenangkan yang mendorong siswa aktif berpartisipasi dalam proses pembelajaran sehingga terjadi peningkatan hasil belajar siswa. Peneliti ingin menggunakan model pembelajaran memanfaatkan teknologi informasi yang dapat mendorong siswa aktif terlibat dan berpikir kreatif selama pembelajaran PPKn sehingga dapat meningkatkan kerativitas serta hasil belajar PPKn.

\section{Kreativitas Siswa}

Kreativitas yaitu kemahiran untuk menyampaikan ide-ide baru dan menerapkannya dalam pemecahan masalah. Sebagaimana yang diungkapkan Munandar (2012:104) bahwa kreativitas adalah suatu kemampuan untuk membuat kombinasi baru berdasarkan unsur atau data informasi yang telah ada dan tersedia, menemukan banyak kemungkinan jawaban terhadap suatu masalah, yang ditekankan pada kualitas, ketepat gunaan dan keragaman jawaban yang menunjukkan kelancaran, keluwesan dan orisinalitas berfikir serta kemampuan mengelaborasi suatu gagasan.

Sund dalam Slameto (2015:147-148) seseorang yang berpotensi kreatif memiliki beberapa ciri, antara lain: memiliki rasa penasaran atau ingin tahu yang tinggi; bersikap terbuka pada hal-hal baru; kaya gagasan; memiliki keinginan kuat untuk melakukan penemuan dan penelitian; lebih condong berminat pada tugas yang berat dan tidak mudah; lebih condong mencari dan memberikan jawaban yang lebih luas dan memadai; berdedikasi dan bersemangat juga aktif dalam melakukan tugas; berpikir luwes; mampu menjawab pertanyaan-pertanyaan yang diberikan dan cenderung memberikan jawaban lebih lengkap dan mencukupi; mempu menganalisis dan mensintesis; memiliki gairah mengajukan pertanyaan serta melakukan penelitian; memilki kapabilitas abstraksi yang baik; senang membaca atau mempunyai latar belakang membaca yang banyak.

\section{Hasil Belajar}

Menurut Bloom (dalam Supriono, 2009:67) kemampuan kognitif, afektif, dan psikomotorik adalah suatu kesatuan hasil belajar. Hasil kegiatan pembelajaran yang menunjukkan perubahan mencakup kemampuan kognitif, afektif dan psikomotor berarti menunjukkan perubahan perilaku. Perilaku yang dimaksud secara menyeluruh bukan pada satu aspek. Hal ini sesuai pendapat Suprijono (2013:7) bahwa seluruh aspek potensi kemanusiaan yang berubah adalah bentuk hasil belajar. Hasil belajar merupakan segala bentuk perilaku (baik dari ranah kognitif, afektif, ataupun psikomotoris) yang muncul setelah proses belajar dan bersifat menetap dalam waktu tertentu. Sedangkan menurut Purwanto (2002:82) kemampuan yang didapat oleh seseorang setelah berlangsungnya proses pembelajaran disebut 
dengan hasil belajar. Kemampuan tersebut dapat mengubah tingkah laku individu dalam hal sikap, pengetahuan atau pemahaman, juga keterampilan sehingga menjadi lebih baik dari sebelumnya. Dari pendapat-pendapat tersebut dapat diartikan bahwa perubahan perilaku yang menetap baik dalam ranah kognitif, afektif, dan psikomotor serta seluruh aspek kemanusiaan yang muncul setelah terjadinya proses belajar disebut dengan hasil belajar.

\section{METODE PENELITIAN}

Pendekatan yang digunakan dalam penelitian ini adalah pendekatan kuantitatif. Menurut Riyanto (2007:152) metode kuantitatif yaitu penelitian yang memusatkan perhatian pada variabel-variabel serta hubungan antar variabel satu dengan variabel lainnya. Jenis penelitian yang digunakan penulis adalah penelitian eksperimen semu (Quasi Experimental Research). Penelitian eksperimen menurut pandangan Riyanto (2007:120) merupakan penelitian yang dilaskanakan dengan sistematis, logis dan teliti dengan melakukan kontrol terhadap kondisi. Lebih lanjut menurut Riyanto, dalam penelitian ini terdapat bentuk perlakuan (treatmen) yang diberikan kepada kelas eksperimen menggunakan sebaik-baik literatur yang telah disiapkan, dan untuk menguji keterkaitan dengan kelas eksperimen itu ada pembanding dari kelas kontrol yang dipilih terhadap perlakuan apa yang diberikan kepada kelas tersebut. Adapun rancangan penelitian eksperimen semu adalah Pretest-Posttest Control Group Design sebagaimana dikemukakan Sugiyono (2016:76) adalah seperti pada tabel 1 berikut.

Tabel 1. Pretest-Posttest Control Group Design

\begin{tabular}{llll}
\hline Kelompok & Pretest & Variabel Perlakuan & Posttest \\
\hline Eksperimen & $\mathrm{O} 1$ & $\mathrm{X}$ & $\mathrm{O} 2$ \\
Kontrol & $\mathrm{O} 3$ & & $\mathrm{O} 4$ \\
\hline
\end{tabular}

Keterangan:

$\begin{array}{ll}\text { O1 } & \begin{array}{l}\text { Hasil Pretest pada kelompok } \\ \text { eksperimen }\end{array} \\ \text { O2 } & \begin{array}{l}\text { Hasil Posttest pada kelompok } \\ \text { eksperimen }\end{array} \\ & \\ \text { O3 : Hasil Pretest pada kelompok kontrol } \\ \mathrm{O} 4 \quad \text { : Hasil Posttest pada kelompok kontrol } \\ \mathrm{X} \quad \text { : Perlakuan (treatmen) }\end{array}$

Langkah pembelajaran yang dilakukan di kelas bahwa kelas eksperimen adalah yang diberikan perlakuan pembelajaran dengan penerapan model pembelajaran Flipped Classroom berbasis teknologi informasi. Pada kelas eksperimen Fase 0 Sebelum Kelas (pre class), siswa mempersiapkan diri untuk berpartisipasi dalam kelas virtual dengan mempelajari sendiri di rumah materi yang sudah diunggah guru di media sosial telegram berupa materi bahan baca ataupun link video dan menjawab pertanyaan terkait. Fase 1 saat kelas dimulai (in class), siswa mempresentasikan apa yang dipelajari sebelumnya dalam diskusi di kelas secara virtual. Fase 2, guru memfasilitasi berlangsungnya kegiatan diskusi dengan memberikan umpan balik pertanyaan maupun lembar kegiatan. Fase 3 setelah kelas berakhir (out of class), kegiatan belajar mengajar diakhiri dengan siswa memeriksa pemaamannya dan memperdalam pengetauhannya dengan mengerjakan tugas unjuk kerja dan mengerjakan soal evaluasi. Sedangkan untuk kelompok kontrol tidak diterapkan pembelajaran dengan model Flipped Classroom atau dengan menggunakan model pembelajaran konvensional. Pembelajaran dengan model pembelajaran konvensional yang dimaksuda adalah menggunakan bantuan media gambar, sumber belajar dengan buku teks dan metode diskusi yang divariasikan dengan metode ceramah.

Penelitian ini dilaksanakan di Sekolah Dasar Negeri Bligo Kecamatan Candi Kabupaten Sidoarjo dengan alasan bahwa di sekolah ini belum pernah dilakukan penelitian terkait dengan model pembelajaran Flipped Classroom. Penelitian dilaksanakan pada semester genap tahun pelajaran 2020/2021. Subyek penelitian ini adalah kelas IV A dan Kelas IV B. Kelas IVA 
dengan jumlah siswa sebanyak 21 orang sebagai kelas kontrol, sedangkan kelas IV B sejumlah 23 orang sebagai kelas eksperimen.

Data penelitian dikumpulkan melalui teknik tes melalui intrumen lembar tes kreativitas dan lembar tes hasil belajar siswa. Tes ini berjumlah 10 soal dalam bentuk 5 pilihan ganda, 3 isian dan 2 uraian. Soal tes sebelum digunakan untuk penelitian dilakukan uji coba instrumen untuk mengetahui tingkat validitas dan reliabilitas suatu instrumen.

Data penelitian dianalisis secara statistik melalui teknik uji. Pengujian hipotesis menggunakan taraf signifikansi 5\%. Sebelum dilakukan analisis uji t, terlebih dahulu dilakukan uji asumsi yaitu normalitas dan uji homogenitas. Uji normalitas menggunakan rumus kolmogorof smirnov dan uji homogenitas menggunakan rumus one way anova. Analisi uji hipotesis dalam penelitian ini menggunakan independent sampel $t$ test

\section{HASIL DAN PEMBAHASAN}

Sebelum digunakan untuk penelitian, instrumen yang digunakan divalidasi terlebih dahulu oleh validator ahli. Adapun hasil validasi oleh validator disajikan dalam di bawah ini:

Tabel 2. Hasil Validasi Instrumen Penelitian oleh Validator Ahli

\begin{tabular}{|c|c|c|c|c|c|}
\hline \multirow[b]{2}{*}{ No. } & \multirow[b]{2}{*}{ Instrumen yang divalidiasi } & \multicolumn{3}{|c|}{ Skor } & \multirow[b]{2}{*}{ Predikat } \\
\hline & & V1 & $\mathbf{V 2}$ & $\begin{array}{l}\text { Rata- } \\
\text { Rata }\end{array}$ & \\
\hline 1. & $\begin{array}{l}\text { Rencana Pelaksanaan Pembelajaran } \\
\text { Kelas Eksperimen }\end{array}$ & 3.5 & 3.6 & 3.55 & $\begin{array}{l}\text { Sangat } \\
\text { valid }\end{array}$ \\
\hline 2. & $\begin{array}{l}\text { Rencana Pelaksanaan Pembelajaran } \\
\text { Kelas Kontrol }\end{array}$ & 3.5 & 3.6 & 3.55 & $\begin{array}{l}\text { Sangat } \\
\text { valid }\end{array}$ \\
\hline 3 & Lembar Kerja Peserta Didik & 3.4 & 4.7 & 3.55 & $\begin{array}{l}\text { Sangat } \\
\text { valid }\end{array}$ \\
\hline 4. & Tes Kreativitas Siswa & 3.4 & 3.0 & 3.2 & Valid \\
\hline 5. & Tes Hasil Belajar & 3.7 & 3.0 & 3.35 & Valid \\
\hline
\end{tabular}

Keterangan : V1 = Validator Ahli 1; V2 = Validator Ahli 2

Berdasarkan tabel di atas, dapat dinyatakan bahwa semua instrumen penelitian yang dinilai oleh validator Ahli di bidangnya dinyatakan layak digunakan sebagai instrumen untuk mengumpulkan data penelitian.

Peneliti melakukan ujicoba instrumen penelitian sebelum dilakukan analisis data hasil penelitian. Pada tahap ini uji validitas menggunakan rumus pearson correlation.
Indikator lembar tes kreativitas siswa dan lembar tes hasil belajar memuat 4 butir item soal. Instrumen tes dinyatakan valid apabila $\mathrm{r}_{\text {hitung }}$ lebih besar dari $r_{\text {tabel. }}$ Jumlah seluruh siswa $\mathrm{N}=20$ dengan taraf signifikansi 5\% adalah 0,423 (Priyatno, 2016:144). Dari analisis data menggunakan SPSS diperoleh hasil bahwa keseluruhan tes kreativitas siswa dinyatakan valid

Tabel 3. Hasil Uji Validitas Tes Kreativitas Siswa

\begin{tabular}{cccc}
\hline Item & r Hitung & $\begin{array}{c}\mathbf{r} \\
\text { Tabel }\end{array}$ & Keterangan \\
\hline Butir 1 & 0.673 & 0.423 & Valid \\
Butir 2 & 0.588 & 0.423 & Valid \\
Butir 3 & 0.732 & 0.423 & Valid \\
Butir 4 & 0.520 & 0.423 & Valid \\
\hline
\end{tabular}

Berdasarkan hasil uji validitas tiap butir soal pada tabel 3, semua butir tes kreativitas siswa menunjukkan nilai $r_{\text {hitung }}>r_{\text {tabel}}$, sehingga dapat dikatakan bahwa semua butir tes kreativitas siswa dalam kategori valid dan dapat digunakan sebagai 
instrumen pengumpulan data untuk variabel kreativitas belajar siswa.

Tabel 4. Hasil Uji Validitas Tes Hasil Belajar

\begin{tabular}{cccc}
\hline Item & r Hitung & r Tabel & Keterangan \\
\hline Butir 1 & 0.663 & 0.423 & Valid \\
Butir 2 & 0.657 & 0.423 & Valid \\
Butir 3 & 0.626 & 0.423 & Valid \\
Butir 4 & 0.509 & 0.423 & Valid \\
\hline
\end{tabular}

Berdasarkan hasil uji validitas tiap butir soal tes hasil belajar pada tabel 4 , semua butir soal memiliki nilai $r_{\text {hitung }}>r_{\text {tabel }}$, sehingga dapat disimpulkan bahwa semua butir soal tes hasil belajar siswa dalam kategori valid dan dapat digunakan sebagai instrumen pengumpulan data hasil belajar siswa.

Setelah uji validitas instrumen penelitian dilakukan, langkah selanjutnya peneliti melakukan uji reliabilitas. Hal ini untuk mengetahui apakah instrumen tes sudah reliabel atau belum. Pengujian reliabilias dalam instrumen penelitian yang telah dipercaya dan reliabel akan menghasilkan data yang dapat dipercaya juga. Pada penelitian ini dilakukan uji reliabilitas untuk menguji instrumen lembar tes kreativitas dan tes hasil belajar dengan menggunakan alpha cronbach's melalui program pengolah data SPSS. Kriteria penentuan batas reliabilitas adalah 0,6 (Sundayana, 2014:70). Adapun hasil reliabilitas tes kreativitas dan tes hasil belajar sebagai berikut

\begin{tabular}{ll}
$\begin{array}{l}\text { Tabel 5. Hasil Uji Reliabilitas Tes Kreativitas Siswa } \\
\text { Cronbach's Alpha }\end{array}$ & N of Items \\
\hline .801 & 4 \\
\hline
\end{tabular}

Tabel 6. Hasil Uji Reliabilitas Tes Hasil Belajar

\begin{tabular}{ll}
\hline Cronbach's Alpha & N of Items \\
\hline .722 & 4 \\
\hline
\end{tabular}

Berdasarkan tabel klarifikasi koefisien reliabilitas (Sundayana, 2014:12) diketahui bahwa hasil uji reliabilitas instrumen tes kreativitas dan tes hasil belajar memiliki tingkat reliabel tinggi dengan kriteria $0.60 \leq \mathrm{r}_{\mathrm{xy}} \leq 0.80$ sehingga instrumen ini dapat digunakan dalam penelitian.

Sesuai dengan tujuan dan hipotesis dalam penelitian ini maka data yang diolah dalam penelitian ini berasal dari data tes kreativitas dan hasil belajar siswa. Lembar tes dilaksanakan tiga kali dalam setiap kelas baik kelas eksperimen dan kontrol.
Tes awal dilakukan sebelum diberikan perlakuan atau ketika siswa melakukan pembelajaran ilmu pengetahuan sosial sebelum dilaksanakan treatment. Kelompok data tes awal disebut sebagai kelompok data pretest. Tes akhir dilakukan ketika pelaksanaan treatment di kelas eksperimen dan kontrol. Kelompok data tes akhir disebut sebagai kelompok data posttest. Adapun hasil deskripsi data pretest dan posttest kreativitas siswa dapat dideskripsikan pada tabel di bawah ini.

Tabel 6. Statistik Deskriptif Data Pretest dan Posttest Kreativitas Siswa

\begin{tabular}{|c|c|c|c|c|c|}
\hline \multirow{3}{*}{ No. } & \multirow{3}{*}{ Deskripsi } & \multicolumn{4}{|c|}{ Nilai Kreativitas Siswa } \\
\hline & & \multicolumn{2}{|c|}{ Kelas Eksperimen } & \multicolumn{2}{|c|}{ Kelas Kontrol } \\
\hline & & Pretest & Posttest & Pretest & Posttest \\
\hline 1. & Rata-Rata & 62.05 & 86.36 & 60 & 78.64 \\
\hline 2. & N-Gain & \multicolumn{2}{|c|}{0.68} & \multicolumn{2}{|c|}{0.50} \\
\hline
\end{tabular}


Jurnal PAJAR (Pendidikan dan Pengajaran)

Volume 5 Nomor 5 September 2021 | ISSN Cetak : 2580 - 8435| ISSN Online : 2614 - 1337

DOI : http://dx.doi.org/10.33578/pjr.v5i5.8462

\begin{tabular}{llcccc} 
3. & Nilai Terendah & 45 & 70 & 40 & 60 \\
4. & Nilai Tertinggi & 80 & 100 & 80 & 100 \\
\hline
\end{tabular}

Berdasarkan penjelasan di atas, diketahui pada kelompok data pretest kreativitas siswa di kelas eksperimen dan kontrol terdapat sedikit perbedaan pada aspek nilai rata-rata. Perbedaan nilai rata-rata pada kelompok data pretest antara kelas eksperimen dan kontrol ialah sebesar 2.05. Dengan demikian, pada kondisi awal atau sebelum diberikan perlakuan kedua kelas memiliki kreativitas siswa yang hampir sama. Sedangkan pada kondisi posttest terdapat perbedaan yang cukup banyak pada aspek nilia rata-rata. Perbedaan nilai rata-rata posttest kemampuan berpikir kreatif siswa antara kelas eksperimen dengan kontrol ialah sebesar 7.72.

Tabel 7. Statistik Deskriptif Data Pretest dan Posttest Tes Hasil Belajar Siswa

\begin{tabular}{clccccc}
\hline & & \multicolumn{5}{c}{ Nilai Hasil Belajar Siswa } \\
No. & \multicolumn{1}{c}{ Deskripsi } & \multicolumn{2}{c}{ Kelas Eksperimen } & \multicolumn{2}{c}{ Kelas Kontrol } \\
\cline { 3 - 6 } & & Pretest & Posttest & Pretest & Posttest \\
\cline { 3 - 6 } 1. & Rata-Rata & 60 & 83.86 & 59.77 & 76.82 \\
2. & N-Gain & & 0.63 & & & 0.44 \\
3. & Nilai Terendah & 40 & 65 & 40 & 60 \\
4. & Nilai Tertinggi & 80 & 100 & 80 & 95 \\
\hline
\end{tabular}

Berdasarkan penjelasan di atas, diketahui pada kelompok data pretest tes hasil belajar siswa di kelas eksperimen dan kontrol terdapat sedikit perbedaan pada aspek nilai rata-rata. Adapun perbedaan nilai rata-rata pada kelompok data pretest antara kelas eksperimen dan kontrol adalah sebesar 0.23. Dengan demikian, pada kondisi awal atau sebelum diberikan perlakuan kedua kelas memiliki tes hasil belajar siswa yang hampir sama. Sedangkan pada kondisi posttest terdapat perbedaan yang cukup banyak pada aspek nilai rata-rata. Perbedaan nilai rata-rata posttest tes hasil belajar siswa antara kelas eksperimen dengan kontrol ialah sebesar 7.04.

Hasil analisis peningkatan hasil belajar siswa kelas eksperimen yang belajar menggunakan model pembelajaran flipped clasroom berbasis teknologi informasi dihitung dengan rumus normalized gain adalah 0.63 , atau meningkat sebesar 63\%. Artinya dalam klasifikasi gain score terjadi peningkatan sedang. Sementara itu, peningkatan hasil belajar siswa di kelas kontrol menggunakan model pembelajaran konvensional dihitung dengan rumus normalized gain adalah 0,44 , atau meningkat sebesar $44 \%$ dalam klasifikasi gain score artinya terjadi peningkatan dengan klasifikasi sedang. Berdasarkan data tersebut dapat disimpulkan bahwa model pembelajaran flipped clasroom berbasis teknologi informasi lebih berpengaruh dalam meningkatkan hasil belajar siswa pada materi keberagaman karakteristik individu muatan pelajaran PPKn pada siswa kelas IV sekolah dasar.

Uji normalitas digunakan untuk menguji apakah data berdistribusi normal atau tidak. Pengujian normalitas digunakan rumus chi-square dengan taraf signifikansi 0,05 atau 5\%, dengan menggunakan SPSS.

Tabel 8. Hasil Uji Normalitas

\begin{tabular}{lcccc}
\hline \multicolumn{1}{c}{ Kelompok } & Kelompok & Nilai Signifikansi & Taraf & Keterangan \\
\hline Kreativitas (pretest) & \multirow{2}{*}{ Ekseprimen } & 0.841 & 0.05 & Normal \\
Kreativits (posttest) & & 0.170 & 0.05 & Normal \\
Hasil belajar (pretest) & \multirow{2}{*}{ Kontrol } & 0.308 & 0.05 & Normal \\
Hasil belajar (posttest) & & 0.736 & 0.05 & Normal \\
\hline
\end{tabular}

Uji normalitas dengan menggunakan rumus kolmogorof dengan taraf signifikansi 5\% yaitu 0.05 . Jika nilai signifikansi $<0.05$ kesimpulannya data tidak berditrubusi normal. 
Namun jika nilai signifikans $>0.05$ maka data tersebut berdistribusi normal. Berdasarkan tabel 6 di atas bahwa semua variabel memiliki nilai lebih dari 0.05 , sehingga dapat dinyatakan bahwa semua variabel penelitian berditribusi normal.

Uji homogenitas ini dilakukan untuk menguji kesamaan dari beberapa bagaian sampel.
Uji homogenitas data tersebut dihitung dengan menggunakan uji levene test dengan kriteria apabila probalitas $(\mathrm{P}>0.05)$ maka sampel bersifat homogen, sedangkan apabila probalittas $(\mathrm{P}<0.05)$ maka sampel bersifat tidak homogen.

Tabel 9. Hasil Uji Homogenitas

\begin{tabular}{lccc}
\hline \multicolumn{1}{c}{ Variabel } & $\begin{array}{c}\text { Nilai } \\
\text { Signifikansi }\end{array}$ & Taraf & Keterangan \\
\hline Kreativitas $($ Pretest $)$ & 0.412 & 0.05 & Homogen \\
Kreativitas $($ Posttest $)$ & 0.602 & 0.05 & Homogen \\
Kreativitas $($ Pretest $)$ & 0.929 & 0.05 & Homogen \\
Kreativitas Posttest $)$ & 0.357 & 0.05 & Homogen \\
\hline
\end{tabular}

Tabel 9 merupakan data uji homogenitas dengan menggunakan taraf signifikansi $5 \%$ yaitu 0.05 . Pengambilan kesimpulannya, jika nilai signifikansi $<0.05$ maka varian kelompok data tidak homogen, dan jika nilai signifikansi $>0.05$ maka varian kelompok data adalah homogen. Berdasarkan tabel diatas, keseluruhan variabel memiliki varian data homogen
Uji hipotesis guna menjawab rumusan masalah dan hipotesis yang diajukan dalam penelitian ini. Uji hipotesis yang digunakan dalam penelitian ini adalah menggunakan uji t. Uji t diperlukan untuk melakukan pengujian tingkat signifikansi antar tiap pengaruh variabel independen kepada variabel dependen secara parsial.

Tabel 10. Pengujian hipotesis

\begin{tabular}{ccccc}
\hline Variabel & T & Df & Sig. (2-tailed) & Deskripsi \\
\hline Kreativitas & 2.405 & 42 & 0.021 & $\mathrm{H}_{\mathrm{a}}$ diterima \\
Hasil Belajar & 2.158 & 42 & 0.037 & $\mathrm{H}_{\mathrm{a}}$ diterima \\
\hline
\end{tabular}

Berdasarkan tabel di atas, dinyatakan bahwa kreativitas siswa memperoleh nilai sig 2 tailed sebesar $0.021<\alpha(0.05)$ dengan $t_{\text {hitung }}>t_{\text {tabel }}$ sebesar (2.405>1.682), maka dapat dinyatakan bahwa Ha diterima. Dengan demikian dapat dinyatakan bahwa terdapat pengaruh yang signfikan pada penggunaan model flipped classroom berbasis teknologi informasi terhadap kreatvitas siswa kelas V sekolah dasar.

Pada variabel hasil belajar siswa memperoleh nilai sig 2 tailed sebesar $0.037<\alpha$ $(0.05)$ dengan $t_{\text {hitung }}>t_{\text {tabel }}$ sebesar $(2.158>1.682)$, maka dapat dinyatakan bahwa $\mathrm{Ha}$ diterima. Dengan demikian dapat dinyatakan bahwa terdapat pengaruh yang signfikan pada penggunaan model flipped classroom berbasis teknologi informasi terhadap hasil belajar siswa kelas V sekolah dasar
Pencapaian tujuan muatan pelajaran PPKn mengharapkan tidak hanya agar siswa dapat berpikir kritis, logis, dan kreatif dalam menanggapi isu kewarganegaraan, namun demikian pula dalam proses pembelajaran siswa dituntut agar bisa beperan aktif, bertanggung jawab, dan bertindak secara cerdas dalam berbagai aktivitas bermasyarakat, berbangsa, dan bernegara, serta anti-korupsi, berkembang secara positif dan demokratis guna membentuk pribadi yang berlandaskan karakter-karakter masyarakat Indonesia agar bisa hidup secara berdampingan dengan bangsa-bangsa lainnya, berinteraksi dengan bangsa-bangsa lain dalam percaturan dunia secara langsung atau tidak langsung dengan memanfaatkan teknologi informasi dan komunikasi. 
Guru memegang peranan penting dalam melaksanakan pembelajaran yang dapat memicu munculnya kreativitas siswa secara keseluruhan, yaitu: bahwa belajar haruslah menjadi hal yang amat berarti dan menciptakan kebahagiaan, siswa harus dihargai dan disayangi sebagai individu yang unik, siswa seyogyanya menjadi pebelajar aktif, siswa harus merasa bebas untuk mendiskusikan suatu masalah, guru hendaknya memberikan pengalaman belajar dalam pembelajaran yang dekat dengan dunia nyata (Slameto, 2015:189). Dengan demikian diharapkan siswa yang mempunyai kreativitas tinggi mampu memecahkan persoalan-persoalan yang dihadapinya dalam pembelajaran, sehingga dengan kreativitasnya siswa mampu meningkatkan hasil belajarnya.

Kreativitas merupakan kemampuan seseorang dalam mengolah ide yang ada, menggabungkan antara ide dan konsep yang mungkin didapatkanya dari proses belajar ataupun pengalaman belajar sebelumnya kemudian mengolahnya menjadi informasi baru. Definisi kreatif adalah kemampuan seseorang untuk menciptakan sesuatu yang baru, baik berupa gagasan atau karya nyata yang relative berbeda dari yang telah ada. Kreativitas merupakan kemampuan berpikir tingkat tinggi yang mengimplikasikan terjadinya eskalasi dalam kemampuan berpikir, ditandai oleh suksesi, diskontinuitas, diferensiasi, dan integrase antara tahap perkembangan (Khoirotunnisa \& Irhadianto, 2020:18). Manusia yang kreatif selalu berusaha untuk memberi makna pad proses belajarnya. Salah satu hal yang mendorong manusia untuk belajar adalah adanya sifat kreatif dalam dirinya dan keinginan untuk maju. Ia tidak pernah takut pada kesalahan dan kegagalan akan mendorongnya pada pencapaian prestasi yang memuaskan. Pendapat lain dikemukakan oleh Munandar (2012:104) bahwa kreativitas adalah suatu kemampuan untuk membuat kombinasi baru berdasarkan unsur atau data informasi yang telah ada dan tersedia, menemukan banyak kemungkinan jawaban terhadap suatu masalah, yang ditekankan pada kualitas, ketepatgunaan dan keragaman jawaban yang menunjukkan kelancaran, keluwesan dan orisinalitas berfikir serta kemampuan mengelaborasi suatu gagasan.
Dalam masa pandemi ini, guru dituntut untuk melaksanakan berbagai inovasi agar pembelajaran tetap bermakna tanpa bertemu secara tatap muka langsung dengan siswa. Pengajar di era sekarang perlu memperhatikan aspek penggunaan teknologi sebagai hal mendasar dalam praktik pembelajaran. Namun demikan, teknologi bukanlah segalanya. Teknologi adalah alat yang dapat dimanfaatkan untuk mendukung terciptanya pengalaman bermakna dalam proses belajar mengajar. Mengingat sebagian besar siswa kita saat ini adalah generasi $\mathrm{Z}$ yang dengan senang hati dan mudah menerimanya dikarenakan mereka sudah lahir dan tumbuh dengan kemajuan teknologi saat ini. Penerapan model pembelajaran flipped classroom dirasa dapat membawa efek yang baik bagi kreativitas dan hasil belajar siswa khususnya dalam pembelajaran daring.pada masa pandemi Covid-19 ini.

Guru berharap dapat menerapkan suatu model pembelajaran yang dikembangkan dengan berbasis teknologi informasi dan sesuai dengan teori pendidikan. Model pembelajaran yang menawarkan cara-cara unik yang terhubung dengan siswa, mengembangkan kemampuan representasi, berkolaborasi, dan menilai proses pembelajaran. Harapan guru tersebut, di latar belakangi oleh banyaknya siswa yang sudah familiar dengan gawai, baik itu berupa smartphone, tablet maupun laptop. Mereka seringkali mengakses segala sesuatu yang disukai dan ingin diketahuinya melalui internet dan jejaring social. Menjadi hal yang mengkhawatirkan jika siswa mengakses internet tanpa mengenal kebermanfaatanya secara tepat, sehingga guru mencoba mengakomodir trend kebiasaan siswa tersebut dengan mengintegrasikanya dalam suatu model pembelajaran yang juga siswa sukai. Bahkan di era teknologi ini, guru berharap siswa bisa belajar dimana saja dan dengan sumber belajar apa saja, dari arah pembelajaran tatap muka konvensional ke ranah pembelajaran terbuka (Andriyani \& Suhendri, 2019).

Berpikir kreatif sangat penting dikembangkan untuk membantu memecahkan permasalahan, dan mencari alternatif pemecahan masalah. Berpikir kreatif ini menjadi bekal utnuk menghadapi permasalahan yang ada terutama 
dalam era globalisasi ini (Damayanti, et al., 2020). Pentingnya pengembangan berpikir kreatif juga dituangkan di dalam tujuan pendidikan nasional yaitu mengembangkan potensi siswa agar menjadi manusia yang bertakwa kepada Tuhan Yang Maha Esa, berakhlak mulia, sehat, berilmu, cakap, kreatif, mandiri, dan menjadi warga negara yang demokratis serta bertanggung jawab. Pemberdayaan berpikir kreatif pada proses pembelajaran di sekolah akan menginternalkan watak ataupun kecenderungan siswa untuk dapat berpikir kreatif

Flipped classroom mengubah model instruksi pembelajaran yang biasanya arahan dan penjelasan datangnya langsung dari guru kepada peserta didik menjadi pembelajaran yang arahan dan penjelasannya dapat diakses oleh peserta didik secara online di luar ataupun di dalam kelas. Model pembelajaran Flipped Classroom memiliki beberapa manfaat, diantaranya adalah (1) Siswa memiliki kesempatan untuk memahami arahan dan penjelasan dari guru secara mandiri ataupun kolaboratif di dalam ataupun di luar kelas secara online. (2) Guru dapat memastikan bahwa setiap siswa telah memahami materi - materi yang diajarkan di luar ataupun di luar kelas. (3) Siswa dapat meningkatkan kapasitas pembelajaran secara mandiri. Selain itu, terjalinnya komunikasi yang aktif antar peserta didik dan guru di luar ataupun di dalam kelas ketika pembelajaran Imania \& Bariah (2020:46). Selain itu, Pendidikan memiliki peranan yang sangat penting dalam menghasilkan sumberdaya yang seutuhnya baik secara individu maupun sebagai anggota masyarakat. Maka untuk menghasilkan Sumber Daya Manusia yang berkualitas terutama dalam bidang teknologi (Susanto, 2015)

Berdasarkan penjelasan tersebut, maka keterkaitan teori Vygotsky terhadap model pembelajaran flipped classroom yakni kecakapan untuk menciptakan alat bantu belajar melalui video atau konten interaktif untuk dipelajari siswa sebelum memualai kelas agar siswa lebih berdiskusi dan memecahkan permasalahan pembelajaran dengan bekal pengetahuan yang diperoleh sebelumnya. Serta terciptanya hubungan yang lebih personal antara guru dan siswa saat pembimbingan di kelas virtual supaya siswa mempunyai tanggungjawab terhadap kegiatan belajarnya.

Hasil belajar dapat tercapai apabila guru dalam menyampaikan pelajaran tidak menjadikan siswa hanya sebagai objek belajar, tetapi siswa dijadikan sebagai subyek, sehingga siswa bisa terlibat langsung dalam proses pembelajaran. Selain itu juga, guru tidak hanya menggunakan model pembelajaran yang monoton, tetapi guru harus bisa mengembangkan model pembelajaran yang bervariasi dan menyenangkan agar siswa senang dalam mengikuti pelajaran dan dapat meningkatkan hasil belajar siswa. Keaktifan siswa tidak saja dalam menerima informasi tetapi juga dalam memproses informasi tersebut secara efektif, mulai mencari pasangan, berdiskusi, menyajikan, bertanya dan menjawab pertanyaan. Keberhasilan belajar dalam muatan pelajaran PPKn dapat dicapai jika dalam prosesnya siswa yang akan membentuk dan merasakan sendiri pengetahuan itu yang didapatnya melalui berbagai bentuk interaksi. Salah satunya dengan menerapkan model pembelajaran flipped classroom.

Suyono dan Hariyanto (2011:9) belajar merupakan aktivitas atau proses guna mendapatkan pengetahuan, berkembangnya keterampilan, memperbaiki perilaku dan sikap, serta memperkokoh personaliti seseorang. Ranah pengetahuan atau kognitif adalah mengetahui, memahami, menerapkan, menganalisis menyintesis, dan mengevaluasi. Ranah kognitif ini dapat diamati dari hasil kegiatan evaluasi setelah menerima pengalaman belajar. Hasil belajar tersebut dapat digunakan sebagai bukti pencapaian tujuan belajar dan peningkatan kemampuan siswa. Sejalan dengan pendapat yang dikemukakan oleh Rahmawati (2015:31) dalam tesisnya yang menyatakan bahwa kemampuan seorang siswa dalam mencapai tujuan dapat dibuktikan dengan hasil kegiatan evaluasi diakhir kegiatan pelajaran.

Menurut Song, et al (2017) bahwa flipped classrom merupakan model pembelajaran interaktif yang didesain secara tepat untuk mendorong pembelajaran yang mengaktifkan siswa, sehingga dalam mengembangkan konteks tatanan kemampuan berpikir yang lebih tinggi siswa harus aktif terlibat dalam kegiatan 
pembelajaran yang bersifat kolaborasi dan pembelajaran berbasis masalah. Pembelajaran interaktif ini dilakukan dengan menukar atau membalik prosedur pembelajaran yang mana pembelajaran konvensional dengan metode ceramah yang umumnya dilakukan di dalam kelas diubah menjadi penyampaian materi pembelajaran oleh guru melalui unggahan di media sosial dalam bentuk audio atau rekam suara, video, situs web, permainan dan simulasi dalam sebuah konten dan lain sebagainya. Selanjutnya di dalam kelas siswa secara aktif menggunakan waktunya guna mendiskusikan hal-hal yang belum dimengerti serta memperdalam pemahamannya dengan cara menyelesaikan persoalan dengan tingkat kesulitan yang lebih tinggi atau higher order thinking skill (HOTS) dengan pendampingan dan bimbingan dari guru.

Konsep model pembelajaran flipped classroom berbasis teknologi informasi mencakup active learning dan keterlibatan siswa Choiroh et al (2018:4). Dalam flipped classroom, materi terlebih dahulu diberikan melalui video pembelajaran yang harus dilihat siswa dirumah masing-masing. Sebaliknya, waktu belajar di kelas digunakan untuk diskusi kelompok dan mengerjakan tugas. Disini guru berperan sebagai pembina atau pemberi saran. Hal ini berarti siswa dituntut untuk belajar secara mandiri. Hal yang sering terjadi pada saat pembelajaran, siswa sering merasa jenuh dan kurang bersemangat dalam menerima materi yang disampaikan oleh guru. Ketika menyampaikan materi kepada siswa seharusnya guru menentukan terlebih dahulu model pembelajaran yang semenarik mungkin agar siswa tertarik dengan pembelajaran tersebut. Dengan model pembelajaran flipped classroom berbasis teknologi informasi siswa dapat menentukan sendiri kondisi belajar yang mereka inginkan, siswa dapat mendiagnosa kebutuhan belajarnya, dan dapat meningkatkan perilaku siswa berdasarkan inisiatif mereka sendiri.

Peran seorang guru di dalam proses belajar mengajar, khususnya dalam hal menyiapkan pembelajaran yang baik dan penggunaan metode dan model mengajar yang sesuai dengan kebutuhan materi yang diajarkan. Sebelumnya telah dijelaskan di atas bahwa model pembelajaran yang digunakan masih berpusat kepada guru dan secara tidak langsung juga mempengaruhi motivasi belajar siswa. Dengan demikian metode dan model yang selama ini digunakan dalam proses belajar mengajar, guru bisa mengganti metode dan model yang lebih bervariasi sehingga dapat meningkatkan pemahaman peserta didik. Penulis memutuskan untuk mengambil model pembelajaran yang dianggap tepat untuk pembelajaran adalah model pembelajaran flipped classroom, flipped classroom merupakan kegiatan membalik prosedur belajar langsung yang biasanya dilakukan di kelas, dalam pembelajaran flipped classroom berpindah dilaksanakan di rumah melalui materi yang dibagikan oleh guru. Materi pembelajaran yang dibagikan baik berupa power point, video maupun buku online, sedangkan di kelas kegiatan untuk meningkatkan penalaran siswa melalui problem solving dengan melakukan kegiatan berdiskusi dan mempersentasikan hasil diskusi mengenai studi kasus yang diberikan oleh guru.

Perkembangan teknologi di era globalisasi memberikan dampak secara langsung terhadap kualitas mutu pendidikan saat ini, sehingga tidak dapat dihindarkan lagi dalam kegiatan belajar mengajar. Salah satu usaha yang dapat dilakukan untuk mengembangkan potensi peserta didik yaitu melalui jenjang pendidikan yang bisa dilakukan dalam proses belajar mengajar, dengan memfasilitasi dan mendorong kegiatan belajar mereka. Sumber daya manusia yang cerdas, unggul dan mampu bersaing secara kompetitif dan mencapai tingkat hidup yang lebih tinggi dapat tercipta melalui pendidikan yang baik menerima materi (Hasbullah, 2013:1). Apabila masih ada materi yang belum dipahami, siswa dapat bertanya kepada guru/teman yang pandai saat tatap muka di kelas.

Perubahan era ini tidak dapat dihindari oleh siapapun sehingga dibutuhkan penyiapan sumber daya manusia (SDM) yang memadai agar siap menyesuaikan dan mampu bersaing dalam skala global. Peningkatan kualitas SDM melalui jalur pendidikan mulai dari pendidikan dasar dan menengah hingga ke perguruan tinggi adalah kunci untuk mampu mengikuti perkembangan Revolusi Industri 5.0 (Arjunaita, 2020). Pendidikan 5.0 adalah respons terhadap kebutuhan revolusi 
industri 5.0 di mana manusia dan teknologi diselaraskan untuk menciptakan peluang-peluang baru dengan kreatif dan inovatif. Belajar pada waktu dan tempat yang berbeda. Siswa akan memiliki lebih banyak kesempatan untuk belajar pada waktu dan tempat yang berbeda. E-learning memfasilitasi kesempatan untuk pembelajaran jarak jauh dan mandiri.

Hasil belajar mempunyai peranan penting bagi siswa untuk mengetahui sejauh mana tingkat keberhasilan dalam mengikuti pembelajaran yang disajikan guru, terutama mengenai penggunaan strategi pembelajaran yang sudah sesuai atau belum (Walidah, et al., 2020). Oleh karena itu, seharusnya guru bisa lebih kreatif dalam menggunakan sebuah model pada muatan pelajaran PPKn yang dapat memberikan kesempatan siswa untuk menjadi aktif di dalam kelas, sehingga suasana belajar mengajar menjadi menyenangkan. Menurut Johnson (2013) model pembelajaran Flipped classroom merupakan model pembelajaran dengan cara meminimalkan jumlah instruksi langsung tapi memaksimalkan interaksi satu-satu. Dengan model flipped classroom siswa dapat belajar dari video terkait materi manfaat keberagaman karakteristik individu yang diberikan oleh guru, sehingga dalam belajar siswa tidak mudah bosan karena hanya mendengarkan penjelasan dari seorang guru. Pada pembelajaran dengan flipped classroom siswa mempelajari topik secara individu, biasanya menggunakan pelajaran video yang dibuat oleh instruktur. Karena siswa dapat mengakses video dimanapun, maka siswa dapat belajar dimana saja dan di ulang-ulang, akibatnya ketika proses pembelajaran diulang-ulang, maka berpengaruh pada hasil belajar.

Salah satu kelebihan model pembelajaran flipped classroom adalah siswa dapat mempelajari materi pelajaran dalam kondisi dan suasana yang nyaman dengan kemampuannya. Hal ini sejalan dengan pendapat Fulton dalam (Yulhendri \& kurniawati, 2016) menyatakan beberapa keunggulan penggunaan flipped classroom. Keunggulan tersebut yaitu: 1) siswa dapat berkembang sesuai kecepatan masing-masing, 2) melakukan latihan yang biasanya menjadi PR di dalam kelas memberikan gambaran yang lebih baik kepada pendidik tentang gaya belajar berikut juga kesulitan belajar siswa, 3) waktu tatap muka dapat dimanfaatkan secara lebih efektif dan kreatif, 4) guru dapat lebih mudah menilai prestasi, minat dan komitmen belajar siswa, 5) penggunaan teknologi membuat pembelajaran lebih fleksibel dan cocok untuk pembelajaran di abad 21 .

Hal ini selaras dengan pendapat Bergmann \& Sam (2012:125) mengemukakan pendapat bahwa model flipped classroom merupakan model pendekatan pedagogis inovatif yang berfokus pada pengajaran yang berpusat pada siswa dengan cara membalik sistem pembelajaran kelas tradisional yang selama ini guru lakukan. Pada pembelajaran flipped classroom terjadi kegiatan pembelajaran campuran di mana siswa terlebih dahulu diberikan konten pembelajaran online bisa berupa video atau konten pembelajaran online lainnya untuk dipelajarinya, biasanya di rumah, dan pekerjaan rumah dilakukan di kelas dengan guru dan siswa berdiskusi dan menyelesaikan pertanyaan atau permasalahan yang disajkian dalam materi pembelajaran. Interaksi guru siswa lebih dipersonalisasi dengan bimbingan secara daring, bukan.dengan ceramah yang lebih bersifat searah. Selain itu, model pembelajaran Flipped classroom merupakan pembelajaran yang mengutamakan kemandirian siswa dalam belajar dan memanfaatkan waktu di luar kelas dengan didukung oleh berbagai teknologi, sehingga dapat memaksimalkan waktu di kelas agar membuka peluang bagi siswa aktif terlibat dalam pembelajaran sosial dan kolaboratif (Mazur, Brown \& Jacobsen, 2015).

Poin utama dari teori belajar Piaget dalam model pembelajaran fliped classroom yaitu ketika siswa membangun pengetahuan dalam penuntasan tugas secara sendiri dan berkelompok ketika siswa bekerjasama dalam kelompok. Salah satu syarat dalam menentukan pengelompokan belajar siswa yaitu mempertimbangkan kemajuan perkembangan siswa. Dalam kelompoknya siswa melakukan pembahasan terkait permasalahan yang menjadi tugas kelompoknya sendiri-sendiri, sedangkan guru senantiasa membimbing saat siswa mengalami kesulitan. 


\section{SIMPULAN DAN REKOMENDASI}

Berdasarkan hasil penelitian yang telah dianalisis, maka hasil penelitian disimpulkan bahwa (1) ada pengaruh model pembelajaran flipped classroom berbasis teknologi informasi terhadap kreativitas siswa pada muatan pelajaran PPKn materi manfaat keberagaman karakteristik individu kelas IV sekolah dasar; dan (2) ada pengaruh model pembelajaran flipped classroom berbasis teknologi informasi terhadap hasil belajar siswa pada muatan pelajaran PPKn materi manfaat keberagaman karakteristik individu kelas IV sekolah dasar. Pembelajaran flipped classroom terjadi kegiatan pembelajaran campuran di mana siswa terlebih dahulu diberikan konten pembelajaran online bisa berupa video atau konten pembelajaran online lainnya untuk dipelajarinya dan pekerjaan rumah dilakukan di kelas dengan guru dan siswa berdiskusi dan menyelesaikan pertanyaan atau permasalahan yang disajkian dalam materi pembelajaran.

$$
\text { Guru diharapkan dalam proses }
$$
pembelajaran dapat memanfaatkan model pembelajaran flipped classroom berbasis teknologi informasi karena model ini berpengaruh terhadap kreativitas dan hasil belajar siswa. Selain itu, model ini dapat dijadikan sebagai solusi untuk pembelajaran dari rumah atau pembelajaran online yang dilakukan siswa saat ini karena dampak pandemi covid-19

\section{DAFTAR PUSTAKA}

Andriyani., \& Suhendri. (2019). Model Flipped Classroom menggunakan pendekatan problem based learning. Jurnal Pemberdayaan: Publikasi Hasil Pengabdian kepada Masyarakat, 3 (3), 287-292.

DOI: https://doi.org/10.12928/jp.v3i3.941.

Aqib, Z., \& Murtadho, A. (2016). Kumpulan Metode Pembelajaran. Bandung: PT. Sarana Taruna Nurani Sejahtera.

Arjunaita. (2020). Pendidikan Di Era Revolusi Industri 5.0. Prosiding Seminar Nasional Pendidikan Program Pascasarjana Universitas PGRI Palembang, 179-196.

Budiyanto, M. Agus Krisno. (2016). SINTAKS 45 Model Pembelajaran dalam Student
Centered Learning (SCL). Malang: Universitas Muhammadiyah Malang Press

Bergmann, J., \& Sams, A. (2012). Flip Your Classroom: Reach Every Student in Every Class Every Day. USA: ISTE ASCD

Choiroh, A. N. L., Ayu, H .D., \& Pratiwi, H. Y. (2018). Pengaruh Model Pembelajaran Flipped Classroom Menggunakan Metode Mind Mapping Terhadap Prestasi dan Kemandirian Belajar Fisika. Jurnal Pendidikan Fisika, 7 (1), 1-5. DOI:

https://doi.org/10.22611/jpf.v7i1.9545.

Damayanti, S. A., Santyasa, I. W., \& Sudiatmika, A. A. I. A. R. (2020). Pengaruh Model Problem Based-Learning Dengan Flipped Classroom Terhadap Kemampuan Berpikir Kreatif. Jurnal Kependidikan, 4 (1), 83-98. DOI: https://doi.org/10.21831/jk.v4i1.25460.

Enfield, J. (2013). Looking at the Impact of the Flipped Classroom Model of Intruction on Undergraduate Multimedia Student at CSUN. TechTrends, 57 (6), 14-27.

Hasbullah. (2013). Dasar-dasar Ilmu Pendidikan. Jakarta: Rajawali Pers

Hidayat, H., Mulyani, H., Fatimah, A. S., Sholihat, A., \& Latifah, A. Z. (2020). Penerapan Metode Mind Mapping untuk Meningkatkan Kreativitas pada Pembelajaran Pendidikan Kewarganegaraan. Jurnal Pendidikan, $21 \quad$ (1), 38-50. DOI: https://doi.org/10.33830/jp.v21i1.546.20 $\underline{20}$.

Imania, K. A. N., \& Bariah, S. H. (2020). Pengembangan Flipped Classroom Dalam Pembelajaran Berbasis Mobile Learning Pada Mata Kuliah Strategi Pembelajaran. Jurnal Pendidikan Teknologi Informasi dan Komunikasi, 6 (2), 45-50. DOI: https://doi.org/10.31980/jpetik.v6i2.859.

Ismail, S. S., \& Abdulla, S. A. (2019). Virtual Flipped Classroom: New Teaching Model to Grant The Learners Knowledge 
And Motivation. Journal of Technology and Science Education, 9 (2), 168-183. DOI: https://doi.org/10.3926/jotse.478

Johnson, G.B. (2013). Student Perceptions of The Flipped Classroom. Columbia: The University of British Columbia.

Khoirotunnisa, A. U., \& Irhadtanto, B. (2020). Pengaruh Model Pembelajaran Flipped Classroom Tipe Traditional Flipped Berbantuan Video Terhadap Kemampuan Berpikir Kreatif Siswa Pada Materi Bangun Ruang Sisi Datar. Jurnal Pendidikan Edutama, 7 (2), 17-23. DOI: http://dx.doi.org/10.30734/jpe.v7i2.768.

Knewton. (2011). Flipped Classroom: A New Method of Teaching Turning The Traditional Classroom on Its Head. New York. Tersedia di http://www.knewton.com/flippedclassroom

Maolidah, I. S., Ruhimat, T., \& Dewi, L. (2017). Efektivitas Penerapan Model Pembelajaran Flipped Classroom Pada Peningkatan Kemampuan Berpikir Kritis Siswa. Edutechnologia, 3 (2), 160-170.

Mazur, A. D., Brown, B., \& Jacobsen, M. (2015). Learning Designs Using Flipped Classroom Instruction. Canadian Journal of Learning and Technology, 41 (2), 1-16

McCarthy, J. (2016). Reflections On A Flipped Classroom In First Year Higher Education. Issues in Educational Research, 26 (2), 332-350

Mujtahidin. (2017). CIVIC EDUCATION DI SEKOLAH: Penguatan Pendidikan Karakter Melalui Pembelajaran PKn yang Inovatif dan Efektif. Surabaya: Pustaka Radja.

Munfaridah, L. (2017). "Penerapan Model Pembelajaran Flipped Classroom untuk Melatih Kemandirian Belajar Siswa dalam Pembelajaran Matematika". Tesis. Surabaya: UIN Sunan Ampel.

Munandar, U. (2004). Pengembangan Kreativitas Anak Berbakat. Jakarta: Rineka Cipta

Nasution. (2011). Kajian Pembelajaran IPS di Sekolah. Surabaya: Unesa University
Press

Priyatno, D. (2014). SPSS22: Pengolahan Data Terpraktis. Yogyakarta: CV. Andi Offset Purwanto, N. (2002). Psikologi Pendidikan. Bandung: Remaja Rosda Karya.

Qodir, Z. (2018). "Hibriditas Kultural dan Radikalisme". Dalam Harian KOMPAS, Rabu, 11 April 2018, halaman 7.

Riyanto, Y. (2007). Metodologi Penelitian Pendidikan. Surabaya: Unesa University Press

Roehl, A., Linga, A., \& Shannon, G. J. (2013). The flipped classroom: An opportunity to engage millennial students though active learning strategies. Journal of Family \& Consumer Science, 105 (2), 44-49.

Rokhaniyah, H. (2017). Flipped Classroom: Can It Optimize Students' Ability To Find Out Main Ideas In Listening Comprehension?. Jurnal Pendidikan, 8 (2), 179-182.

Ruminiati. (2006). Pembelajaran Pendidikan Kewarganegaraan SD. Jakarta: Dirjen Dikti Depdiknas

Rusman., Kurniawan, D., \& Riyana, C. (2013). Pembelajaran Berbasis Teknologi Informasi dan Komunikasi: Mengembangkan Profesionalitas Guru. Jakarta: Raja Grafindo Persada.

Rusnawati, M. D. (2020). Implementasi Flipped Classroom Terhadap Hasil dan Motivasi Belajar Siswa. Jurnal Ilmiah Pendidikan dan Pembelajaran, 4 (1), 139-150.

Sahara, R., \& Sofya, R. (2020). Pengaruh Penerapan Model Flipped Learning dan Motivasi Belajar Terhadap Hasil Belajar Siswa. Jurnal Ecogen, 3 (3), 419-431. DOI:

http://dx.doi.org/10.24036/jmpe.v3i3.99 18.

Santoso, H. (2019). Strategi Penguatan Implementasi Nilai-Nilai Pancasila dalam Konteks Kekinian. Prosiding Seminar Nasional Penguatan Implementasi Nilai-Nilai Pancasila di Era Kekinian. Diselenggarakan oleh P4TK PKn dan IPS Malang di Batu Malang, 22 Oktober 2019 
Siregar, S. (2014). Metode Penelitian Kuantiatif. Jakarta: Kencana Prenada.

Slameto. (2015). Belajar dan Faktor-Faktor yang Mempengaruhinya. Jakarta: Rineka Cipta

Song, Y., Jong, M., \& Chen, W. (2017). "HOW” to Design, Implement and Evaluate the Flipped Classromm?. Journal of Educational Technology \& Society, 20 (1), 180-183

Sugiyono. (2016). Metode Penelitian Pendidikan Pendekatan Kualitatif, Kuantitatif, dan R $\& D$. Bandung: Alfabeta.

Sundayana, R. (2014). Statistika Penelitian Pendidikan. Bandung: Penerbit Alfabeta.

Suprijono, A. (2013). Cooperative Learning Teori dan Aplikasi PAIKEM. Yogyakarta: Pusaka Pelajar

Suyono \& Hariyanto. (2017). Belajar dan Pembelajaran. Bandung: Rosdakarya

Walidah, Z., Wijayanti, R., \& Affaf, M. (2020). Pengaruh Model Pembelajaran Flipped Classroom (FC) terhadap Hasil Belajar. Edumatica, 10 (2), 71-77

Winarno. (2014). Pembelajaran Pendidikan Kewarganegaraan: Isi, Strategi, dan Penilaian. Jakarta: Bumi Aksara

Yulhendri, Y., \& Kurniawati, T. (2016). Flipped Learning Berbasis Web Pada Pembelajaran di Universitas Negeri Padang. DOI: https://doi.org/10.31227/osf.io/s37vj. 